УДК: 004.023

\title{
An interactive tool for developing distributed telemedicine systems
}

\author{
V. P. Guskov ${ }^{1, a}$, D. E Gushchanskiy ${ }^{2}$, N. V. Kulabukhova ${ }^{2}$,

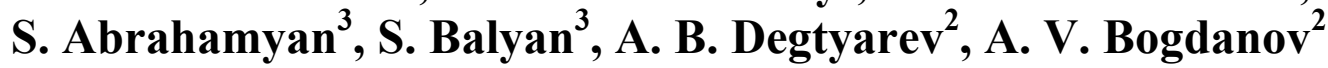 \\ ${ }^{1}$ Herzen State Pedagogical University of Russia, Moika river embankment 48, St. Petersburg, 191186, Russia \\ ${ }^{2}$ Saint Petersburg State University, University ave., 35, Peterhof, St. Petersburg, 198504, Russia \\ ${ }^{3}$ State Engineering University of Armenia (Polytechnic), Teryan Str. 105, Yerevan, 0009 Republic of Armenia \\ E-mail: "avadim.p.guskov@gmail.com
}

Received October 1, 2014

Getting a qualified medical examination can be difficult for people in remote areas because medical staff available can either be inaccessible or it might lack expert knowledge at proper level. Telemedicine technologies can help in such situations. On one hand, such technologies allow highly qualified doctors to consult remotely, thereby increasing the quality of diagnosis and plan treatment. On the other hand, computer-aided analysis of the research results, anamnesis and information on similar cases assist medical staff in their routine activities and decision-making.

Creating telemedicine system for a particular domain is a laborious process. It's not sufficient to pick proper medical experts and to fill the knowledge base of the analytical module. It's also necessary to organize the entire infrastructure of the system to meet the requirements in terms of reliability, fault tolerance, protection of personal data and so on. Tools with reusable infrastructure elements, which are common to such systems, are able to decrease the amount of work needed for the development of telemedicine systems.

An interactive tool for creating distributed telemedicine systems is described in the article. A list of requirements for the systems is presented; structural solutions for meeting the requirements are suggested. A composition of such elements applicable for distributed systems is described in the article. A cardiac telemedicine system is described as a foundation of the tool

Keywords: artificial intelligence, decision support systems, distributed telemedicine systems, interactive tool, remote consultations

The work is partly supported by Resource Center "Computer Center SPbSU" and project 9.38.674.2013 of SaintPetersburg State University.

Citation: Computer Research and Modeling, 2015, vol. 7, no. 3, pp. 521-527.

(C) 2014, Вадим Павлович Гуськов, Дмитрий Евгеньевич Гущанский, Наталия Владимировна Кулабухова, Сурен Арменович Абраамян, Сероб Гургенович Балян, Александр Борисович Дегтярев, Александр Владимирович Богданов 


\title{
Интерактивный инструментарий для распределенных телемедицин- ских систем
}

\author{
В. П. Гуськов ${ }^{1}$, Д. Е. Гущанский ${ }^{2}$, Н. В. Кулабухова ${ }^{2}$, С. А. Абраамян ${ }^{3}$, С. Г. Балян ${ }^{3}$, \\ А. Б. Дегтярев ${ }^{2}$, А. В. Богданов ${ }^{2}$
}

${ }^{I}$ Российский государственный педагогический университет им. А. И. Гериена,

Россия, 191186, г. Санкт-Петербург, набережная реки Мойки, д. 48

${ }^{2}$ Санкт-Петербургский государственный университет,

Россия, 198504, г. Санкт-Петербург, Петергоф, Университетский просп., д. 35

${ }^{3}$ Государственный инженерный университет Армении (Политехник),

Республика Армения, 375009, г. Ереван, ул. Терьяна, д. 105

Для жителей удалённых районов часто может составлять проблему прохождение квалифицированного медицинского обследования. Доступный медицинский персонал может отсутствовать или не обладать экспертными знаниями достаточного уровня. Помочь в такой ситуации могут телемедицинские технологии. С одной стороны, такие технологии позволяют врачам высокой квалификации оказывать удалённые консультации, повышая тем самым качество постановки диагноза и составления плана лечения. С другой стороны, средства автоматизированного анализа результатов проведённых исследований, анамнеза и информации об аналогичных случаях помогают облегчить выполнение рутинных действий и оказать медицинскому персоналу поддержу в принятии решений.

Создание телемедицинской системы для конкретной предметной области — это трудоёмкий процесс. Не достаточно подобать подходящих специалистов и заполнить базу знаний аналитического модуля. Необходимо также организовать всю инфраструктуру системы, удовлетворяя предъявляемые требования по надёжности, отказоустойчивости, защите персональных данных и так далее. Снизить трудоёмкость разработки телемедицинских комплексов может инструментарий, содержащий многократно используемые инфраструктурные элементы, общие для систем такого рода.

В данной работе описан интерактивный инструментарий для создания распределённых телемедицинских систем. Приводится список требований, предъявляемый к получаемым системам, и архитектурные решения, позволяющие удовлетворить эти требования. В качестве примера применения созданного инструментария описывается кардиологическая телемедицинская система.

Ключевые слова: интерактивный инструментарий, искусственный интеллект, распределённые телемедицинские системы, системы поддержки принятия решений, удалённые консультации 


\section{Introduction}

In a narrow sense, telemedicine is a procedural complex for transporting medical data at a distance via computer technologies and high-trunk connection. However, the modern state of information technologies allows considering telemedicine as an interdisciplinary field focused on creation of the unified information space that contains ordered resources and functions of the different subjects of healthcare.

The necessity of telemedicine development is acknowledged by the leading countries of the world. For instance, telemedicine technologies are widely used by USA, Norway, Greece, Great Britain and many others [Телемедицинские центры и ресурсы..., 2014]. Projects of telemedicine networks formations are considered among the most important medical projects funded by European Community. They are particularly important for the countries with vast remote areas, where traditional medicine availability is lacking [К вопросу развития телемедицины..., 2013]. Considering the large geographic extent of Russian Federation, the significance of such problems is growing continuously.

While a huge variety of telemedicine systems is being used for different purposes: remote surgery, videoconferences and consultations, medical e-learning and others, the most important branch of telemedicine in Russia is providing highly-qualified medical treatment for people regardless of their location. Appropriate medical services should be available in rural hospitals, towns with a lack of specialists, remote settlements without any medical institutions, during expeditions and so on.

With the growth of IT-infrastructure and network speed, the need for efficient distributed medical data processing increases. It creates a problem of the medical data protection, which should be handled with personal rights and state security in mind [Рыжов, 2011].

Commonly, remote consulting is considered as a basic function of telemedicine systems. The function includes deferred and real-time consulting via text messages or video, medical data transmission and analysis.

Remote consulting can be extended to videoconferences. Vast experience in holding videoconferences, even international ones, proves the efficiency of the approach. Russia is systematically involved in the number of videoconferences such as Moscow - San Francisco, Moscow - Geneva, Arkhangelsk — Oslo etc [Юсупов и др., 2002].

Another steadily growing part of telemedicine is the development and use of electronic health records (EHR). EHR are the key part of implementation of distributed health technologies. They grant easy access to medical history and thereby increase the efficiency of medical consulting and treatment. Consolidation of databases which belong to different medical facilities provides wide range of possibilities for statistical analysis and data mining.

In addition to consulting and medical data handling, medical e-learning is a significant component of the telemedicine. According to the analysis of different telemedicine projects from various countries, $48 \%$ of the projects are related to medical educational purposes [К вопросу развития телемедицины..., 2013]. The remote consulting, information support of general practitioners and medical scientists, lifelong distance learning determine the complete solution for problems of telemedicine application by improving the training of specialists. Periodical issues of the journal of medical education 'Academic Physician \& Scientist' about the topic could be considered as a proof of large interest in educational aspects of telemedicine.

Synthetic technologies of medical data processing are rapidly being developed as a part of telemedicine. They consist of different kinds of information, expert and intelligent systems. Their aggregating factor is an AI-based knowledge extraction from medical data and providing this knowledge in the form of decision support systems [Нечаев, Дегтярев, 2011]. Automated consultations using various diagnostic systems are considered to be the main focus of such systems application. Their purpose is to support decision making about appropriate treatment on real cases, utilizing achievements in theoretical and practical techniques of AI. A lot of factors and the complexity of interactions during medical decision making are the reason why medicine is one of the most difficult areas to apply automatic logic inference [Богданов и др., 2003]. There may be a number of reasons: 
The complexity of medical knowledge impedes problem solving because of lack of standardization in terminology, formats and measurement scales. Diagnostic system encodings are becoming more and more universal lately, however the extensive range of symptoms, data acquisition formats and organization of records storage still remain a matter of personal preference;

Flexible and easy to use computer methods of medical knowledge representation have not been created yet. The same could be told about flexible algorithms of inference;

Large amount and complexity of medical knowledge result in high requirements on computer systems for its storing and processing. So far, such requirements could have only been met using mainframes with different 'intelligent' terminals, which have various processing and visualization speed;

There is no any 'driving force' capable to encourage the spread of such computer systems and their inclusion into medical practice.

Medical theory and practice are quite complex. The lack of clear definitions of deceases and conditions of the organism, parallel classifications, various and sometimes doubtful measurement scales complicate the work of physicians. The effective telemedicine usage requires development of strict encoding and diagnostic standards. The unified terminology is important for knowledge formalization for intelligent systems. The standardization will help to solve the problem of introducing new technologies and defining knowledge bases for new generation of medical information systems more precisely.

The main requirements for the development of decision support systems in medical applications are associated with flexibility and ability to evolve and provide practical advices in the environment with information heterogeneity. Hierarchical system pattern, the possibility of connecting networks, operational reliability and survivability as well as continuity and the ability to upgrade continuously make such systems extremely complex both in development and maintenance.

Creating a telemedicine system for a particular domain is a laborious process. It is not enough to find qualified medical experts and to fill the knowledge base of the analytical module. It is also necessary to organize all infrastructure of the system to meet the requirements in terms of reliability, fault tolerance, protection of personal data and so on. The motivation of current work is to create a toolkit for a broad range of telemedicine systems to decrease the amount of work needed for the development of telemedicine systems.

\section{The research foundation}

The idea of creating tools for development of distributed telemedicine systems is based on experience with ADEPT-C software package. ADEPT-C (Advanced Data Evaluation Parallel Tools - in Cardiology) is designed to ensure the correct functionality of a RTCES (Real-Time Cardiology Expert System) [Bogdanov et al., Volume 1, Issue 2, 2006]. Its purpose is to arrange data collection of remote patients' statuses, formation of EHRs and decision making support for diagnosing physicians in the form of automated consultations. It implements a software shell for a cardiology real-time expert system designed for operational control and medical consulting of patients with cardiovascular diseases who are at a considerable distance from the leading medical centers. ADEPT-C operates on clientserver architecture and uses multiprocessor supercomputers as its core. ADEPT-C toolkit is the basis for creating a new generation of RTCES functioning on high performance supercomputers [Bogdanov et al., Volume 1, Issue 3, 2006]. The system includes components which can be implemented as reusable components and used as a basis in creating modern distributed telemedicine systems in specific problem areas, thus it served as a foundation of the present work. Below is the short description of the system functionality [Bogdanov et al., Volume 1, Issue 1, 2006].

The RTCES is intended for use only by persons with special medical training and system authorization. These persons are divided into the following categories:

- Physician generalists. The category includes primary care physicians, family physicians, emergency room doctors and medical staff providing medical stations in organizations with high requirements on workers' health (e.g. airports, railroad stations, etc). 
- Specialists. This category contains the problem area specialists from clinics and hospitals. The main difference from the first group is their expertise in identification of specific symptoms, which are the base of the differential diagnosis.

- Experts. This group consists of leading specialists in the medicine problem area who have mastered their diagnosis skills and are capable of making additional changes to the knowledge base of the system.

According to the three groups of users, the system allows performing the following tasks:

- Automated anamnesis collection and conducting EHR of a personalized patient, including his or her passport and insurance information, results of the current survey and inspection, medical devices data, the diagnosis;

- Automated remote consulting - the decision making support for the attending physician (generalist) in order to create a further diagnosis;

- Automated differential diagnosis - the decision making support for the attending specialist in order to establish a final diagnosis. This task is performed based on the results of an automated consultation;

- Real-time remote expert consulting for an attending physician (performed on the results of automated consultations in ambiguous cases);

- Education and training of physicians.

ADEPT-C software package is designed to accomplish the following tasks:

- Allowing users (based on their permissions) to access to a single database containing information about patients.

- Organization of rule-based inference for the differential diagnosis of cardiac diseases.

- Stochastic modeling of human heart electrical activity in order to detect and diagnose its pathological dynamics.

- Modification and adoption of new information into the database and the knowledge base of RTCES based on the results of the current system usage.

- Protection of personal data during their transfer between components of the complex.

The fundamentally essential part of the telemedicine complex organization is knowledge and experience transfer from leading research institutions, therapeutic and diagnostic centers to physicians and other specialists who are far away. Interconnection of computer systems into a single telecommunication network under the multilevel structure based on a telemedicine resource center allows implementation of knowledge integration and rapid transfer of structured data between separate contributors for the further usage in diagnosis and treatment.

\section{Architecture of the system}

There are four main components in the designed interactive tool (see figure 1). The first is a facade - component that is responsible for interaction with external environment. It provides API for creating client applications for specific problem areas, e.g. services of data access and consultation requests. In addition, the facade contains modules of encrypted data transfer and user authorization and authentication.

The second component is the remote consultation organization module. It maintains the list of available specialists and a queue of patients, for which diagnosis is required. When doctor is ready for the next case, the module chooses patient from the top of the priority queue and helps to establish connection between them.

The medical data storage is the third toolkit component. The main part of it is the distributed database for history of cases. The tool user can deploy the database nodes on his hardware and configure the structure of stored EHRs. Furthermore, the component contains API for integration of external data sources. Records from extraneous data warehouses should be converted for the further usage in the system.

The last component - automatic consultation module — can be seen on the figure 2 . The central part of that module is the inference engine. Its function is to provide recommendations by means of 
logical reasoning. The engine uses information from different sources. First, it has access to knowledge base filled in by problem area experts. Using rules from knowledge base and symptoms from working memory, the reasoner provides the most possible diagnosis. Additional information can be extracted by statistical analysis of anonymous records from data storage. Furthermore, the module contains procedure components registry. External procedures can be integrated into the system using this registry. Procedure can add extra facts to working memory and precise existed symptoms.

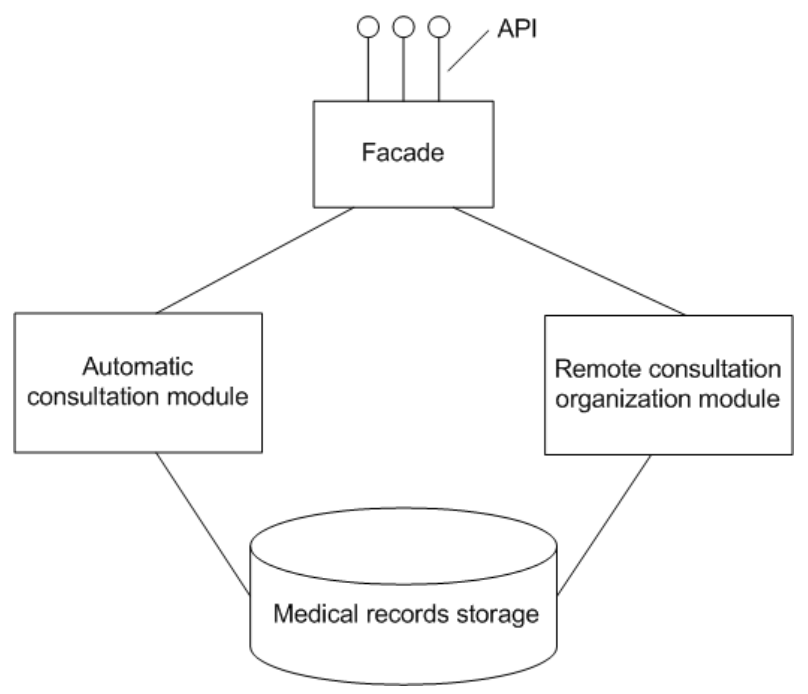

Fig. 1. Common architecture

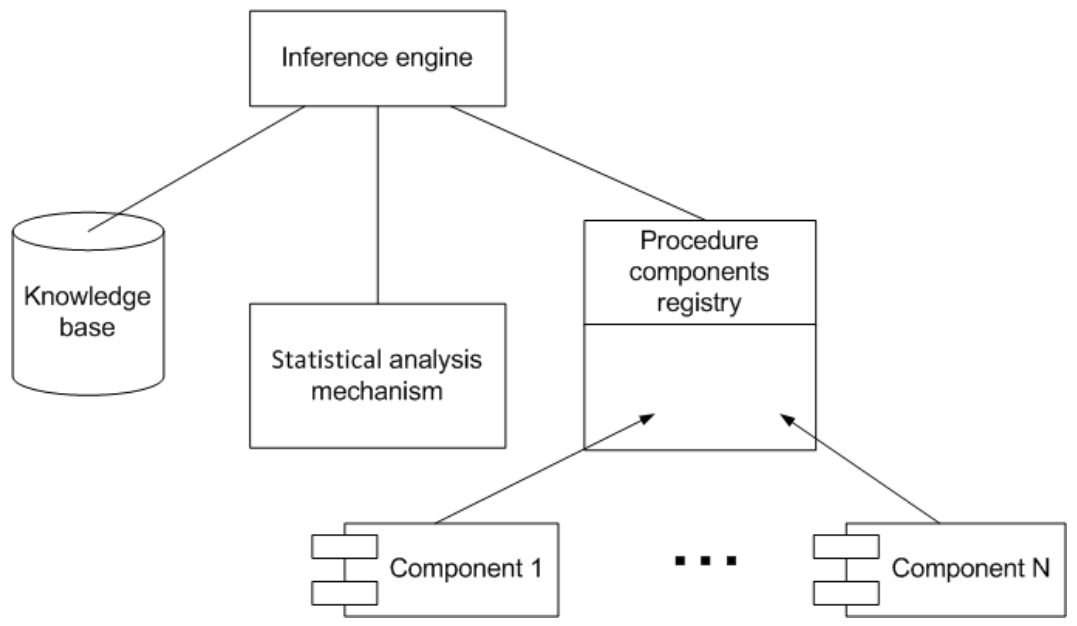

Fig. 2. Automatic consultation module

Summarizing the previous topics, the list of the interactive tool functions is presented below:

- Medical data storage;

- Encrypted data transfer;

- User authorization and authentication;

- Client API;

- Inference engine;

- Distributed knowledge base;

- Statistical analysis tool;

- Procedure component registry. 
These activities are useful for creation of telemedicine system infrastructure. If the tool takes responsibility to provide these functions, it will be easier to construct the telemedicine system for specific problem area.

\section{Conclusion}

The present work is an initial stage for future development. Creation of such tools allows faster implementation of functionalities of information systems for telemedicine purposes. A fast and easy way to create telemedicine systems can boost their use in healthcare and greatly improve the quality of life.

\section{References}

К вопросу развития телемедицины в Республике Армения [Текст] / М. Н. Авакян [и др.] // Медицинское образование и профессиональное развитие. - 2013. - № 4. - С. 42-54.

Нечаев Ю. И., Дегтярев А. Б. Интеллектуальные системы: концепция и приложения. - СПб.: Изд-во С.-Петерб. ун-та, 2011. — 269 с.

Богданов А. В., Бухановский А. В., Вальденберг А. В., Дегтярев А. Б., Нечаев Ю. И. Информационно-аналитическая система в области телемедицины. Патент на изобретение RUS 225196529.01 .2003$.

Рыжов P. С. Актуальные проблемы правового обеспечения накопления конфиденциальной информации о гражданах в телемедицине // Теория и практика общественного развития. 2011. — №7. - С. 247-249.

Юсупов Р. М., Полонников Р. И., Дюк В. А., Блажис А. К., Кувакин В. И., Иванов А. Ю., Воробьев О. В., Сотников А. Д. Развитие телемедицины на Северо-Западе России // Труды СПИИРАН. Вып. 1, т. 1 - СПб: СПИИРАН, 2002.

Телемедицинские центры и ресурсы Internet по телемедицине. Функции телемедицинских центров. 2014. fzoz.ru/articles/informatsionnye-tekhnologii-dlya-vracha-glava-26-telemeditsinskietsentry-i-resursy-interne

Bogdanov A., Degtyarev A., Nechaev Y., Valdenberg A. Designing a High-Performance Telemedicine System. // Healthcare IT Management, Volume 1, Issue 2, Euromedical Communications NV, Brussels, Belgium, 2006 - P. 30-32.

Bogdanov A., Degtyarev A., Nechaev Y., Valdenberg A. Designing a High-Performance Telemedicine System, Healthcare IT Management, Volume 1, Issue 3, Euromedical Communications NV, Brussels, Belgium, 2006. - P. 31-34.

Bogdanov A., Degtyarev A., Nechaev Y., Valdenberg A. Designing a High-Performance Telemedicine System, Healthcare IT Management, Volume 1, Issue 1, Euromedical Communications NV, Brussels, Belgium, 2006. - P. 29-32. 